\title{
Socioeconomic status in Brazilian psychological research: I. validity, measurement, and application
}

\author{
Rodolfo de Castro Ribas Jr. \\ Universidade Federal do Rio de Janeiro \\ Maria Lucia Seidl de Moura \\ Universidade do Estado do Rio de Janeiro \\ Isabela Dias Soares \\ Alessandra Aparecida do Nascimento Gomes \\ Universidade Federal do Rio de Janeiro \\ Marc H. Bornstein \\ National Institute of Child Health and Human Development - USA
}

\begin{abstract}
This review has several objectives: To describe and discuss theoretical conceptions of the construct of socioeconomic status (SES) and to argue for its vital role in psychological research; to present and analyze procedures employed to measure SES and trends in their utilization; and to review and discuss the use of SES measures in Brazilian psychological literature. The relative position of individuals, families, and groups in a given hierarchy (frequently converted into a score produced by a scale) is what has usually been called SES. The main indicators and procedures used to measure SES are discussed in regard to its advantages and disadvantages. A review of the literature offers evidence of the importance of the SES in different psychological processes. A systematic evaluation of articles from the PsycARTICLES database was conducted and revealed that the percentage of articles published annually that employed socioeconomic status increased steadily and substantially from 1988 through 2000 and that SES has been consistently applied more in some research areas (e.g., developmental, clinical, social psychology). A content analysis of the use of SES in articles published from 1981 through 2001 in three prominent Brazilian psychology journals was conducted showing that reliable SES measures are not commonly used in the Brazilian psychological literature. The results of these reviews and analyses are discussed in terms of their implications for further progress of psychological literature, especially in Brazil, with regard SES.
\end{abstract}

Key words: socioeconomic status; brazilian research; measurement; validity

\section{Resumo}

Status socioeconômico na pesquisa psicológica brasileira: I. validade, mensuração e aplicação. Esta revisão teve os seguintes objetivos: descrever e discutir concepções teóricas acerca do constructo status socioeconômico (SSE) e argumentar no sentido de seu papel vital na pesquisa psicológica; apresentar e analisar procedimentos empregados para medir SSE e tendências em sua utilização; rever e discutir a utilização de medidas de SSE na literatura psicológica brasileira. A posição relativa de indivíduos, famílias e grupos em uma determinada hierarquia (freqüentemente convertida em um escore produzido por uma escala) é o que tem sido freqüentemente chamado de status socioeconômico. Os principais indicadores de SSE são discutidos em relação a suas vantagens e desvantagens. Uma avaliação sistemática de artigos da base de dados PsycARTICLES foi conduzida e revelou que a percentagem de artigos publicados anualmente que empregou o status socioeconômico aumentou sistemática e substancialmente de 1988 a 2000. No entanto, SSE é consistentemente mais aplicado em certas áreas de pesquisa do que em outras (e.g., psicologia do desenvolvimento, clínica e social). Uma análise de conteúdo do uso do SSE em artigos publicados de 1981 até 2001 em três periódicos de psicologia brasileiros qualificados foi realizada. O principal resultado dessa análise é de que medidas confiáveis de SSE não são comumente utilizadas na literatura psicológica brasileira. Os resultados das revisões e análises são discutidos em termos de implicações para o aprimoramento da literatura psicológica com relação a essa variável (SSE), especialmente no Brasil.

Palavras-chave: status socioeconômico; pesquisas brasileiras; medida; validade 
I nterest in social and cultural settings and their influence on psychological processes has been strong since the beginnings of psychology, but has grown significantly in the last decades. Furthermore, recognition that context is relevant for understanding many psychological processes has translated into efforts to situate individuals, families, and groups according to social criteria (Bronfenbrenner \& Morris, 1998). Socioeconomic status (SES) is one prominent contextual variable, and it has pervasive influence in psychology (e.g., Argyle, 1994; Adler et al., 1994) and especially on parenting and child development (e.g., Bornstein \& Bradley, 2003; Bradley \& Corwyn, 2002). This review has several objectives: To describe and discuss theoretical conceptions of the construct of socioeconomic status and to argue for its vital role in psychological research; to present and analyze procedures employed to measure SES and trends in their utilization; and to review and discuss the use of SES measures in Brazilian psychological literature.

\section{What socioeconomic status is}

The term socioeconomic status usually denotes the relative position of individuals, families, or groups into stratified social systems (Grusky, 1993; Hoff, Laursen, \& Tardif, 2002; Mueller \& Parcel, 1981; Smith \& Graham, 1995). Defined this way, the construct is in turn subsumed by the sociological concepts of social stratification and social inequality. Social inequality refers to the fact that, in virtually all societies, critical social values (e.g., education, occupation, economic resources, prestige, power, information) are not uniformly distributed. Social stratification refers to the process of organization of social systems (e.g., societies) where individuals, families, and groups are classified into hierarchies (e.g., social classes) according to their access or control of education, wealth, prestige, power, and the like. Social inequality is a result of complex processes of social stratification that hierarchically distribute people according to their access to these values and resources (e.g., Grusky, 1993; Mueller \& Parcel, 1981). The relative position of individuals, families, and groups in a given hierarchy is frequently converted into a score produced by a scale, and SES is normally indexed by one or a combination of the following prominent indicators: education, occupation, and income (see Bornstein, Hahn, Suwalsky, \& Haynes, 2003).

Out of an interest in SES, psychologists have often focused on the impact of poverty on psychological processes. However, several authors have asserted that poverty and SES are not interchangeable constructs (Duncan \& BrooksGunn, 2000; Huston, McLoyd, \& Garcia-Coll, 1997; McLoyd, 1998). In psychological research, poverty has usually been conceptualized as the relative position of individuals, families, or groups above or below a poverty line, a governmental or national index based on monetary income (see the U.S.A. Bureau of the Census, as cited in Entwisle \& Astone, 1994, p. 1527). However, poverty can also be evaluated in different terms. The human poverty index for developing countries computed by the United Nations, for instance, measures poverty along three basic dimensions: long and healthy life, knowledge, and decent standards of living, as measured by the probability at birth of surviving to age 40 ; adult illiteracy rate; the percentage of the population not using improved water sources; and the percentage of children under 5 who are underweight (United Nations Development Programme [UNDP], 2001, p. 241).

Recent studies have also distinguished objective from subjective SES (e.g., Adler, Epel, Castellazzo, \& Ickovics, 2000; Ostrove, Adler, Kuppermann, \& Washington, 2000). Subjective SES has been conceptualized as the individual's perception of his or her own relative position in society in terms of education, occupation, and income. Other authors have used the construct of economic pressure or financial strain to evaluate the impact of objective socioeconomic conditions over individuals and families (e.g., Conger et al. 1993, 1994; Conger, Reuter, \& Elder, 1999, Simons, Lorenz, Wu, \& Conger, 1993). Objective economic hardship exerts its influence on families through a mediating chain of events that includes perceived economic pressure (see also McLoyd, 1998). Because subjective accounts of SES have been relatively infrequent in psychological research, this article focuses on objective SES.

\section{Socioeconomic status in social scientific and psychological research}

The specification of SES plays several key roles in psychological science. First, SES is a key sociodemographic marker variable (Entwisle \& Astone, 1994; Hernandez, 1997; Hoff et al., 2002). It is essential to document the sociodemographic characteristics of study participants (Bell \& Hertz, 1976; Gottfried, 1985) to describe the characteristics of the study sample adequately and to ensure proper comparability and generalizability. Second, SES is regularly associated with a wide variety of human health and disorder indexes as well as, third, in particular with variations in parenting and child development (e.g., Palacios, 1990; Sameroff \& Feil, 1985). In spite of these several key motives, however, the use of SES in psychological science, although increasingly popular, is still ad hoc and "rather loose" in operationalization and measurement (Smith \& Graham, 1995).

Strong bidirectional relations between SES and health have been systematically and consistently reported in the sociological, epidemiological, and psychiatric literatures. SES is associated with rates of mortality and morbidity from almost every type of physical disease and disorder (Adler et al., 1994; Anderson \& Armstead, 1995; Belle, 1990; Dohrenwend \& Schwartz, 1995; Jayakody, Danziger, \& Kessler, 1998; Johnson et al., 1999; Marmot et al., 1997; Ostrove \& Adler, 1998; WHO - International Consortium in Psychiatric Epidemiology, 2000). Similar significant connections exist between SES and a wide variety of psychological processes. National and cross-national studies using large samples have shown that the prevalence of virtually all types of mental disorders (e.g., psychosis, affective, anxiety, and personality disorders) is related to SES (Adler et al., 1994; Dohrenwend \& Schwartz, 1995; Jayakody, Danziger, \& Kessler, 1998; Johnson et al., 1999; Marmot et al., 1997; Rogler, 1996). For example, a 
cross-national study conducted on a sample of 29,644 people in seven countries (Brazil, Canada, Germany, Holland, Mexico, Turkey, and United States) by the World Health Organization - International Consortium in Psychiatry Epidemiology ([WHO-ICPE], 2000) showed the prevalence of anxiety, mood, and substance-use disorders was significantly related to the main indicators of SES, education, occupation, and income. Likewise, three large-scale studies, two American and one British that together mobilized more than 40,000 participants, associated SES with the prevalence of a wide variety of physical and mental disorders, as well as subjective wellbeing (Marmot et al., 1997).

Several reviews have confirmed the relevance of SES to parenting and child development particularly (e.g., Bradley \& Corwyn, 2002; Collins et al. 2000; Duncan \& Brooks-Gunn, 2000; Hetherington, Bridges, \& Insabella, 1998; Hoff et al., 2002; Larson \& Verma, 1999; Lovejoy, Graczyk, O’Hare, \& Neuman, 2000; McLoyd, 1998). For instance, Gottfried (1985) evaluated interrelations among three different SES indexes (the Revised Duncan Socioeconomic Index, the Siegel Prestige Scale, and the Hollingshead Four-Factor Index of Social Status) and measures of development of young children. The three indexes overlapped substantially and presented similar patterns of correlations with children's development. However, the Hollingshead Four-Factor Index of Social Status systematically presented the highest correlations with the developmental status of children. Other investigations have revealed relations between SES and other constructs like intelligence (e.g., Neisser et al., 1996; Suzuki \& Valencia, 1997), mental health (e.g., Adler et al., 1994; Jayakody, Danziger, \& Kessler, 1998; Johnson et al., 1999), self-esteem (Gray-Little \& Hafdahl, 2000), and obesity (Sobal \& Stunkard, 1989). Associations between SES and the development of cognitive and linguistic abilities, for example, have been systematically reported, even when IQ and other psychological characteristics of mothers are controlled. Larson and Verma (1999) presented evidence that children of highest SES families usually dedicate more hours to studying, read more, and watch less TV. The prevalence of anxiety, and depressive, disruptive, and personality disorders in children and adolescents is higher in low-SES families (Johnson et al., 1999).

\section{How socioeconomic status is measured}

There is some dispute over the operationalization of SES and the best way(s) to measure it (e.g., Duncan \& Magnuson, 2003; Ensminger \& Fothergill, 2003; Entwisle \& Astone, 1994; Ganzeboom, De Graaf, \& Treiman, 1992; Hoff et al., 2002; Mueller \& Parcel, 1981; Smith \& Graham, 1995). Sociologists dedicated to the study of social stratification and related processes (such as social mobility or the intergenerational transmission of social inequality; e.g., Warren \& Hauser, 1997) have devoted considerable effort to constructing reliable measures of SES (Ganzeboom, De Graaf, \& Treiman, 1992; Treiman, 1977). Typically, a limited set of sociodemographic variables has been used alone or in combination to measure SES. The indicators used most often are educational attainment, occupational prestige, and financial income. These indicators reflect the main components of social stratification (e.g., Smith \& Graham, 1995) and are usually interrelated, but are not entirely interchangeable (Adler et al., 1994). In the last 50 years, several scales or indexes have been developed to measure SES. Most produce composite scores by computing the weighted sum of sociodemographic variables that are considered relevant to the process of social stratification (Entwisle \& Astone, 1994; Gottfried, 1985). Among the most prominent scales are the Hollingshead Four-Factor Index of Social Status (HI; Hollingshead, 1975) and the Standard International Occupational Prestige Scale (SIOPS; Ganzeboom, \& Treiman, 1996; Treiman, 1977). These and other scales have been constructed using large samples (e.g., data produced in statistical censuses) and, in general, are based on the assumption that SES is a multidimensional construct.

Despite important criticism (e.g., Duncan \& Magnuson, 2003; see also the final part of this section), the Hollingshead Four-Factor Index of Social Status is today the most widely adopted index of SES in psychological research (e.g., Gottfried, 1985). In an analysis of the PsycARTICLES database, Ribas (2001) verified that 367 articles published between 1988 and 2001 employed the Hollingshead Index or its predecessor (the Hollingshead Two-Factor Index of Social Position). In the same period, 61 articles employed some version of the Socioeconomic Index of Occupational Status.

The HI is based on education, occupation, marital status, and gender of each employed householder in a household. Education is based on the number of years of school achievement and is scored on a 7-point scale. Occupation is keyed to the approximate 450 occupational titles from the 1970 United States Census and is scored on a 9-point scale. The HI produces a composite score ranging from 8 through 66 by summing the education score weighted by 3 and the occupation score weighted by 5 . For nuclear families with one spouse gainfully employed, $\mathrm{HI}$ is calculated on the basis of the employed member's education and occupation. For nuclear families with both spouses gainfully employed, spouses' individual HI scores are averaged to obtain a single HI score for the nuclear family.

Given that the HI was developed using data from the U.S. Census, it is reasonable to ask if this SES index has validity outside the U.S.A. and especially in a South American setting. Pascual, Galperín, and Bornstein (1995) tested the validity of the HI in Argentina, and they found a high correlation ( $r=.88$ ) between the HI and an Argentinean index of SES (the Life Style, Education, and Occupation EVEO). Pascual et al. (1995) also verified that these two indexes showed similar patterns of association with lifestyle and maternal perceptions about childrearing.

Comparative research on social stratification and social mobility has made considerable progress toward internationally standardized scales of SES. The classification of occupations is usually the backbone of these scales (Ganzeboom et al., 1992; Ganzeboom \& Treiman, 1996; Nakao \& Treas, 1990; Treiman, 1977). Treiman (1977) presented a theoretical basis for determining the prestige of occupations in complex societies, and based on an analysis of national 
and local prestige studies conducted in approximately 60 countries showed that the prestige of occupations, with few exceptions, does not vary substantially across societies. Treiman (1977) constructed the Standard International Occupational Prestige Scale (SIOPS) by averaging several national prestige scores. The SIOPS initially was coded on the 1968 International Standard Classification of Occupations (ISCO68) of the International Labor Office (ILO) of the United Nations, and was subsequently recoded on the 1988 International Standard Classification of Occupations (ISCO88) by Ganzeboom and Treiman (1996). The revised SIOPS produces scores for more than 500 occupational titles ranging from 6 through 78. A second significant development toward internationally standardized SES scales was accomplished by Ganzeboom, De Graaf, and Treiman (1992), who employed optimal scaling procedures to construct the International Socio-Economic Index of Occupational Status (ISEI). The ISEI was constructed using data on education, occupation, and income from 73,901 full-time employed men in 16 countries and occupational titles derived from ISCO68 (Ganzeboom et al., 1992). The ISEI produces cross-nationally comparable SES measures for international studies of social mobility. The ISEI was also recoded on the ISCO88 by Ganzeboom and Treiman (1996) and produces scores ranging from 16 through 90. The coefficients relating occupational status to education, and occupational status to income, estimated for ISCO88, were .58 and .46, respectively (Ganzeboom \& Treiman, 1996). In the case of Brazil, data came from national research (Pesquisa Nacional por Amostra de Domicílios [PNDA], do Instituto Brasileiro de Geografia e Estatística; Ganzeboom et al., 1992). (Both SIOPS and ISEI can be obtained over the Internet at www.idealibrary.com.)

The construct SES is principally associated with measures of education, income, and occupation (e.g., Bornstein et al., 2003; Heise, 1972). However, the use of SES scales that consist of composite scores of these different measures has been criticized by several researchers (e.g., Bornstein et al., 2003; Duncan \& Magnuson 2003; Hoff et al., 2002). It has been argued, among other things, that the use of composite scales makes it difficult to interpret what mechanisms are responsible for associations between SES and psychological processes. In some cases, education level could be a decisive variable; in other cases, parental occupation or family income could have a larger influence. For this reason, Entwisle and Astone (1994) recommend the use of separate indicators for three different kinds of capital (financial, human, and social) to measure SES. Instead of using either composite indexes or single measures of SES, new research designs have employed several measures of SES simultaneously in order to assess the relative impact of the individual variables.

In a recent study, for example, Bornstein and his colleagues (2003) analyzed the effects of SES on maternal parenting and 5-month infant behavior using two composite multivariate measures of SES (the Hollingshead Four-Factor Index of Social Status and the Socioeconomic Index of Occupations) and their components (e.g., education, occupation, and income). The Hollingshead Index and the
Socioeconomic Index of Occupations overlapped substantially; however, structural equation modeling revealed that only the Hollingshead Index predicted maternal and infant behavior. Even more striking, maternal education was the only Hollingshead component that consistently predicted both maternal and infant behavior.

\section{Socioeconomic status use in psychological research}

Adler and Ostrove (1999) analyzed records of the MEDLINE database and documented the increase in research on socioeconomic status and health between 1980 and 1999. This increase was inferred from substantial growth in the number of articles published annually on health and socioeconomic status.

Science can be understood, in part, as a system where information is mainly produced and transmitted in the form of publications. Based on this assumption, bibliometrics - a range of methods of analysis of scientific literature (e.g., publications, citations) - has been developed to provide quantitative indicators of research activity (see Gilbert, 1978; Spinak, 1998; White \& McCain, 1989). Bibliometric studies have often been used to evaluate trends in selected areas of scientific investigation and to access research performance in countries, geographic areas, and institutions (e.g., Glänzel, 1996; Krauskopf, Pessot, \& Vicuña, 1986; Leta \& De Meis, 1996; Meertens, Blickenstaff, \& Moravcsik, 1982). These studies have also shown that, although not free from limitations, quantitative indicators based on the published scientific literature can be reliable and useful (e.g. Gomes, Sanz, \& Mendéz, 1990; Over, 1978; Sylvain, 1993). Bibliometric analyses have also been performed in psychology to examine trends in collaborative research and publication in psychological journals (Over, 1982), prominence of schools in scientific psychology (psychoanalysis, behaviorism, cognitive psychology, and neuroscience; Robins, Gosling, \& Craik, 1999), paradigmatic changes in modern psychology (Friman, Allen, Kerwin, \& Larzele, 1993), and to provide an overview of Latin American psychology (Vidal, Ferrandiz, Hernadez, \& Linares, 1991).

In this study we evaluated trends in the application of SES in psychological research using procedures similar to those commonly applied in bibliometric studies. The PsycARTICLES database permitted us to scan every word in the text of articles stored in the database of 28 journals published by the APA, 10 specialty journals, 3 journals from the Canadian Psychological Association, and the European Psychology journal. The PsycARTICLES database had stored more than 25,000 full-text electronic journal articles published between 1988 and 2001. All published articles that employed the term socioeconomic status were systematically identified. Records of all articles identified with this procedure were retrieved and processed. These records retained the title, journal, and year of publication of all articles identified.

Altogether, 2175 articles (8.98\% of the database) employed the term socioeconomic status in any part of the text. Figure 1 shows the trend in the utilization of this term from 1988 to 2000: The percentage of articles that employed 


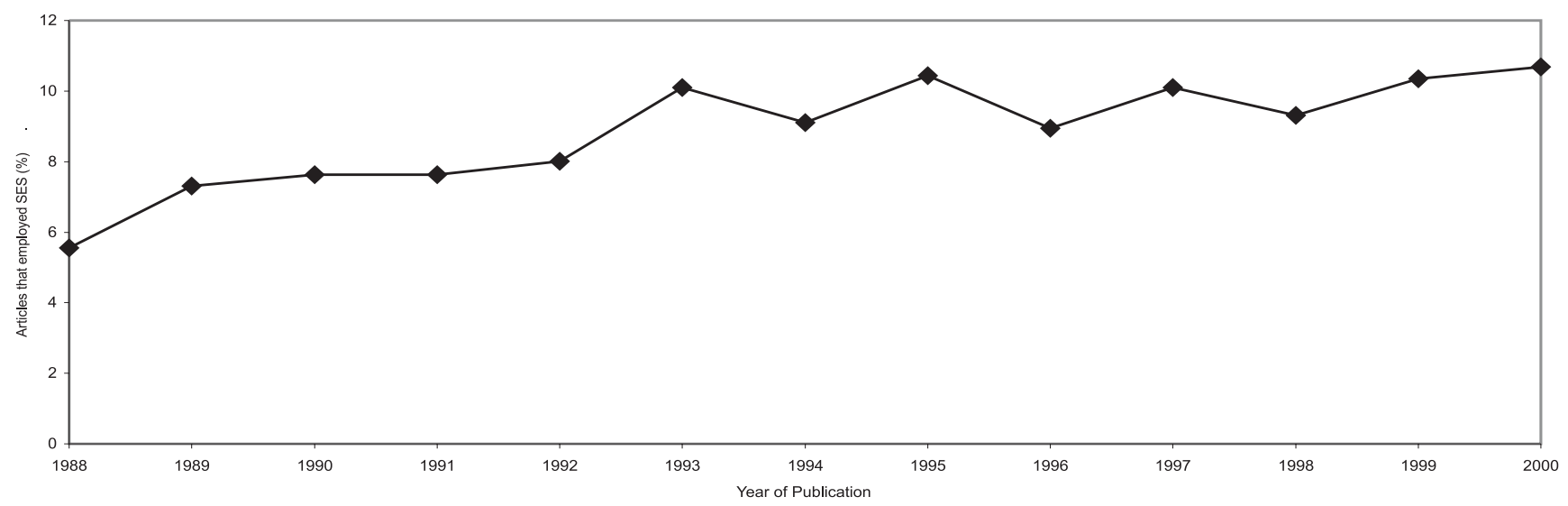

Figure 1. Percentage of articles indexed by PsycARTICLES that employed the term socioeconomic status.

the term socioeconomic status increased steadily from $5.6 \%$ in 1988 to $10.7 \%$ in 2000, almost doubling in 13 years. A regression analysis was conducted to evaluate the increase in percentage of SES articles as a function of year and produced an unstandardized beta of .34 ( $p<.001)$. Nonetheless, only about $10.7 \%$ of all articles stored in PsycARTICLES published in 2000 made explicit reference to the term socioeconomic status, a low percentage given the central importance of the topic in psychology.

The contribution of each of the journals covered by PsycARTICLES to the publication of SES articles was then calculated. We verified that 36 journals published SES articles. Journals that published more than $4 \%$ of these articles were selected. This procedure returned a list of 12 journals that together published $84 \%$ of all SES articles published from 1988 to 2000. Table 1 presents the number of SES articles published from 1988 to 2000 in each of the 12 journals and the percentage that this number represents of the total of SES articles identified in PsycARTICLES database. For each of the 12 journals, we next computed the number of articles mentioning SES.

Table 2 presents the percentage of articles published by each journal from 1998 to 2000 that employed the term socioeconomic status. The percentage of articles varied substantially from journal to journal; for example, SES was identified in $22.9 \%$ of the articles published by Developmental Psychology (a research journal) but in only $6.2 \%$ of the articles published by American Psychologist (a generalist journal) in the same period. Regression analyses were conduced to evaluate trends in the publication of SES articles as a function of year. Table 2 also presents the unstandardized betas computed for each journal. The growth in the percentage of SES-mentioning articles over time was significant $(p<.05)$ in only four of the selected journals. None of the regression analyses revealed a significant decrease $(p<.05)$ in the percentage of SES-mentioning articles.
Table 1

Number and percentage of articles published from 1988 to 2000 and stored in PsycARTICLES database that employed the term socioeconomic status by journal

\begin{tabular}{lrc}
\hline \multicolumn{1}{c}{ Journal } & $\mathrm{N}$ & $\%$ \\
\hline Developmental Psychology & 304 & 13.98 \\
Journal of Consulting and Clinical Psychology & 303 & 13.93 \\
Journal of Abnormal Psychology & 167 & 7.68 \\
Journal of Personality and Social Psychology & 163 & 7.49 \\
American Psychologist & 149 & 6.85 \\
Journal of Educational Psychology & 141 & 6.48 \\
Psychological Assessment & 109 & 5.01 \\
Health Psychology & 105 & 4.83 \\
Psychology and Aging & 103 & 4.74 \\
Psychological Bulletin & 100 & 4.60 \\
Journal of Family Psychology & 92 & 4.23 \\
Journal of Counseling Psychology & 90 & 4.14 \\
Other Journals & 349 & 16.05 \\
\hline Total & 2175 & 100.00 \\
\hline \hline
\end{tabular}


Table 2

Percentage of articles published by journal from 1998 to 2000 that employed the term "socioeconomic status" and unstandardized Beta Coefficients for regression analyses predicting percentage of articles that employed the term socioeconomic status as a function of year for selected journals

\begin{tabular}{|c|c|c|c|}
\hline Journal & $\%$ & B & SE I \\
\hline Journal of Family Psychology & 22.94 & 3.19 & .5 \\
\hline Developmental Psychology & 22.91 & .90 & .31 \\
\hline Health Psychology & 19.89 & .74 & 9 \\
\hline Journal of Consulting and Clinical Psychology & 19.00 & .18 & .1 : \\
\hline Journal of Abnormal Psychology & 17.16 & .81 & .41 \\
\hline Journal of Educational Psychology & 16.77 & .98 & .3 \\
\hline Psychological Assessment & 14.08 & .25 & .41 \\
\hline Psychological Bulletin & 13.76 & .23 & .3 \\
\hline Psychology and Aging & 12.64 & .13 & .5 \\
\hline Journal of Counseling Psychology & 12.18 & .69 & .2 \\
\hline Journal of Personality and Social Psychology & 6.83 & .22 & .1 \\
\hline American Psychologist & 6.23 & .13 & .1 : \\
\hline
\end{tabular}

\section{Socioeconomic status in Brazilian psychological research}

Mueller and Parcel (1981) conducted a content analysis of studies published from 1978 to 1979 in two prominent developmental psychology journals, Child Development and Developmental Psychology. They aimed to identify how the authors of studies in these two journals "conceive of SES, how they measure it, and how it is used in their analyses" (Mueller \& Parcel, 1981, p. 13). Impressionistic criteria or outdated measures were often employed to evaluate SES: For example, many articles stated that "subjects were selected from predominantly middle-class schools in the community X” (Mueller \& Parcel, 1981, p. 14). This approach is unspecific and implies simplistic assumptions about the homogeneity of samples with regard of SES. Ensminger and Fothergill (2003) examined a series of reviews on SES and psychological processes and reached similar conclusions. According to Ensminger and Fothergill (2003), several reviews (e.g. Graham, 1992; MacPhee, Kreutzer, \& Fritz, 1994; Smith \& Graham, 1995) have stressed, among other things, that researchers are not usually concerned with theoretical and methodological issues related to using measures of SES and that measures of SES are simply missing in a significant number of studies.

Taking these and other related considerations into account (e.g., Nunes, 1993), we analyzed the use of SES in the contemporary Brazilian psychological literature. The indicators of SES in Brazilian psychological research in the last three decades were identified using a content analysis of articles published from 1981 through 2001 in three prominent Brazilian psychology journals: Psicologia: Reflexão e Crítica, Psicologia: Teoria e Pesquisa, and Arquivos Brasileiros de Psicologia. Three inclusion criteria were used to select these journals: journals that systematically published psychological studies in the last three decades, journals with nationwide circulation, and journals that received a concept $A$ in the 2000 evaluation of the scientific psychology journals conduced by Associação Nacional de Pesquisa e Pós-Graduação em Psicologia (ANPEPP) and Fundação Coordenação e Aperfeiçoamento de Pessoal de Ensino Superior (CAPES).

A total of 597 research articles was systematically identified and analyzed. Initially, we verified which articles made explicit reference to the SES of participants. Among the articles that did so, we then checked if some SES index or reliable SES indicator (e.g., educational attainment, occupational prestige, and financial income) was employed. To assure the quality of the analysis, about $25 \%$ of the articles included in the study were independently examined by two evaluators (interrater agreement $=92 \%$ ).

From the total number of empirical articles examined, 177 (29.6\%) explicitly supplied information concerning participants' SES. This result corroborates the idea that SES is a variable reasonably often referred to in Brazilian psychological research. However, from the 177 articles that made explicit reference to the SES of the participants, 86 (48.59\%) did not supply any information about how SES was evaluated. Another 43 articles (24.29\%) used unreliable criteria in the determination of the SES: 29 employed some school type classification (e.g., public school, private school, school that assists low-income population), and 14 mentioned some type of locality classification (e.g., slum, periphery, middleclass neighborhood) to characterize the SES of the participants. Only $48(27.12 \%)$ articles used a scale or other acceptable criterion to evaluate the SES. Of these 48, 12 used a composite scale to evaluate SES, 9 used educational attainment as an indicator, 9 used income, and 16 used some combination of two or more components (e.g., educational attainment, occupational prestige, and financial income).

In general, the use of reliable SES measures was infrequent in the investigations examined. It seems reasonable, therefore, to alert researchers to this systematic methodological shortcoming in Brazilian psychological research. Conclusions from investigations about social differences have frequently been formulated on unreliable bases. For instance, studies that use some type of school classification (usually public versus private school) to differentiate the SES of the participants may produce naive and erroneous conclusions. Different and more valid conclusions may be obtained if multiple and reliable SES indicators are employed. 


\section{Conclusions}

The use of socioeconomic status in psychological research was investigated. SES is a highly relevant construct to many areas of psychology. Several SES measures have been developed, and some have become standards in international psychological research. Systematic evaluation of a large amount of information provided by the PsycARTICLES database affirms that the proportion of studies in psychology that employed socioeconomic status increased from 1988 through 2000. In this light, the results of the present content analysis of Brazilian research are disheartening: They reveal too little consideration of SES variables and the use of inaccurate indicators of SES. Brazilian researchers should carefully consider the need to include reliable SES measures in their investigations. Naive classifications based on type of schools or residential neighborhood should be abandoned in favor of standardized SES indexes, including at the very least parental education. Including SES will increase our understanding of Brazilian research participants and allow more valid generalization and better interpretation in psychological research.

\section{Acknowledgements}

Maria Lucia Seidl de Moura was supported by grants from Conselho Nacional de Desenvolvimento Científico e Tecnológico (CNPq) and Fundação Carlos Chagas Filho de Amparo à Pesquisa do Estado do Rio de Janeiro (FAPERJ).

The authors wish to thank Cândice D. Silva, Daniel C. Mograbi, Fernando F. Stern, Gabriela B. Altalf, Gabriela S. F. Rangel, Iana Sudo, Juliana Mezzono, Márcia Ângela M. de F. Lima, Paula C. Pontes, and Roberto L. da Silveira for assistance in data collection and Adriana F. P. Ribas for thoughtful comments on earlier drafts of this article.

\section{References}

Adler, N. E., \& Ostrove, J. M. (1999). Socioeconomic status and health: What we know and what we don't. Annals of the New York Academy of Sciences, 896, 3-15.

Adler, N. E., Boyce, T., Chesney, M. A., Cohen, S., Folkman, S., Kahn, R. L., \& Syme, L. (1994). Socioeconomic status and health: The challenge of the gradient. American_Psychologist, 49, 15-24.

Adler, N. E., Epel, E. S., Castellazzo, G., \& Ickovics, J. R. (2000). Relationship of subjective and objective social status with psychological and physiological functioning: Preliminary data in healthy, White women. [Electronic version]. Health Psychology, 19, 586-592.

Anderson, N. B., \& Armstead, C. A. (1995). Toward understanding the association of socioeconomic status and health: A new challenge for the biopsychosocial approach. Psychosomatic Medicine, 57(3), 213-225.

Argyle, M. (1994). The psychology of social class. New York: Routledge.

Bell, R. Q., \& Hertz, T. W. (1976). Toward more comparability and generalizability of developmental research. Child Development, 47, 6-13.

Belle, D. (1990). Poverty and women's mental health. American Psychologist, 45, 385-389.

Bornstein, M. H., Hahn, C.-S., Suwalsky, J. T. D., \& Haynes, O. M. (2003). The hollingshead four-factor index of social status and the socioeconomic index of occupations. In M. H. Bornstein \& R. H. Bradley (Eds.), Socioeconomic status, parenting, and child_development. Mahwah, New Jersey: Lawrence Erlbaum Associates.

Bornstein, M. H., \& Bradley, R. H. (2003). Socioeconomic status, parenting, and child_development. Mahwah, New Jersey: Lawrence Erlbaum Associates.

Bradley, R. H., \& Corwyn, R. F. (2002). Socioeconomic status and child development. Annual Review of Psychology, 53, 371-399.

Bronfenbrenner, U., \& Morris, P. A. (1998). The ecology of developmental processes. In W. Damon (Series Ed.) \& R. M. Lerner (Vol. Ed.), Handbook of child psychology: Vol. 1. Theoretical models of human development $\left(5^{\text {th }}\right.$ ed., pp. 993-1028). New York: Wiley.

Collins, W. A., Maccoby, E. E., Steinberg, L., Hetherington, E. M., \& Bornstein, M. H. (2000). Contemporary research on parenting: The case for nature and nurture. American_Psychologist, 55, 218-232.

Conger, R. D., Conger, K. J., Elder, G. H., Lorenz, F. O., Simons, R. L., \& Whitbeck, L. B. (1993). Family economic stress and adjustment of early adolescent girls [Electronic version]. Developmental Psychology, 29, 206219.

Conger, R. D., Ge, X., Elder, G. H., Lorenz, F. O., \& Simons, R. L. (1994). Economic stress, coercive family process, and developmental problems of adolescents. Child Development, 65, 541-561.

Conger, R. D., Rueter, M. A., \& Elder, G. H. (1999). Couple resilience to economic pressure [Electronic version]. Journal of Personality and Social Psychology, 76, 54-71.

Dohrenwend, B. P., \& Schwartz, S. (1995). Socioeconomic status and psychiatric disorders. Current Opinion in Psychiatry, 8, 138-141.

Duncan, G. J., \& Brooks-Gunn, J. (2000). Family poverty, welfare reform, and child development. Child Development, 71, 188-196.

Duncan, G. J., \& Magnuson, K. (2003). Off with Hollingshead: Socioeconomic resources, parenting, and child development. In M. H. Bornstein \& R. H. Bradley (Eds.), Socioeconomic_status, parenting, and child development. Mahwah, New Jersey: Lawrence Erlbaum Associates.

Ensminger, M. E., \& Fothergill, M. (2003). A decade of measuring SES: What it tells us and where to go from here. In M. H. Bornstein \& R. H. Bradley (Eds.), Socioeconomic status,parenting, and child development: Mahwah, New Jersey: Lawrence Erlbaum Associates.

Entwisle, D. R., \& Astone, N. M. (1994). Some practical guidelines for measuring youth's race/ethnicity and socioeconomic status. Child Development, 65, 1521-1540.

Friman, P. C., Allen, K. D., Kerwin, M. L., \& Larzelere, R. (1993). Changes in modern psychology: A citation analysis of the Kuhnian displacement thesis. American Psychologist, 48, 658-664.

Ganzeboom, H. B. G., \& Treiman, D. J. (1996). Internationally comparable measures of occupational status for the 1988 International Standard Classification of Occupations. Social_Science Research, 55, 201-239.

Ganzeboom, H. B. G., De Graaf, P. M., \& Treiman, D. J. (1992). A standard international socio-economic index of occupational status. Social Science Research, 21, 1-56.

Gilbert, G. N. (1978). Measuring the growth of science: A review of indicators of scientific growth. Scientometrics, 1(1), 9-34.

Glänzel, W. (1996). A bibliometric approach to social sciences. National research performance in 6 selected social sciences areas, 1990-1992. Scientometrics, 35(3), 291-307.

Gomes, I., Sanz, E., \& Mendéz, A. (1990). Utility of bibliometric analysis for research policy: A case study of research on neuroscience. Research Policy, 19, 457-466.

Gottfried, A. W. (1985). Measures of socioeconomic status in child development research: Data and recommendations. Merrill Palmer Quarterly, 31, 8592.

Graham, S. (1992). "Most of the subjects were White and middle class": Trends in published research on African Americans in selected APA journals, 1970-1989. American Psychologist, 47, 629-639. 
Gray-Little, B., \& Hafdahl, A. R. (2000). Factors influencing racial comparisons of self-esteem: A quantitative review. Psychological Bulletin, 126, 26-54.

Grusky, D. B. (1993). Social stratification. In W. Outhwaite \& T. Bottomre (Eds.), The_Blackwell Dictionary of Twentieth-Century Social Thought. Oxford, England: Blackwell Publishers.

Heise, D. R. (1972). Employing nominal variables, induced variables, and block variables in path analysis. Sociological Methods \& Research, 1, 147-173.

Hernandez, D. J. (1997). Child development and the social demography of childhood. Child_development, 68, 149-169.

Hetherington, E. M., Bridges, M., \& Insabella, G. M. (1998). What matters? What does not? Five perspectives on the association between marital transitions and children's adjustment. American Psychologist, 53, 167184.

Hoff, E., Laursen, B., \& Tardif, T. (2002). Socioeconomic status and parenting. In M. H. Bornstein (Ed.), Handbook of parenting (Vol. 2, pp. 231-252). Mahwah, New Jersey: Lawrence Erlbaum Associates.

Hollingshead, A. B. (1975). The four-factor index of social status. Unpublished manuscript, Yale University.

Huston, A. C., McLoyd, V. C., \& Garcia-Coll, C. (1997). Poverty and behavior: The case for multiple methods and levels of analysis [Electronic version]. Developmental Review, 17, 376-393.

Jayakody, R., Danziger, S., \& Kessler, R. C. (1998). Early-onset psychiatric disorders and male socioeconomic status [Electronic version]. Social Science Research, 27(4), 371-387.

Johnson, J. G., Cohen, P., Dohrenwend, B. P., Link, B. G., \& Brook, J. S. (1999). A longitudinal investigation of social causation and social selection processes involved in the association between socioeconomic status and psychiatric disorders [Electronic version]. Journal of Abnormal Psychology, 108, 490-499.

Krauskopf, M., Pessot, R., \& Vicuña, R. (1986). Science in Latin America. How much and along what lines? Scientometrics, 10(3/4), 199-206.

Larson, R. W., \& Verma, S. (1999). How children and adolescents spend time across the world: Work, play, and developmental opportunities. Psychological Bulletin, 125, 701-736.

Leta, J., \& De Meis, L. (1996). A profile of Science in Brazil. Scientometrics, 35(1), 33-44.

Lovejoy, M. C., Graczyk, P. A., O’Hare, E., \& Neuman, G. (2000). Maternal depression and parenting behavior: A meta-analytic review. Clinical Psychology Review, 20, 561-592.

MacPhee, D., Kreutzer, J. C., \& Fritz, J. J. (1994). Infusing a diversity perspective into human development courses. Child Development, 65, 699-715.

Marmot, M., Ryff, C. D., Bumpass L. L., Shipley, M., \& Marks, N. F. (1997). Social inequalities in health: Next questions and converging evidence. Social Science and Medicine, 44, 901-910.

McLoyd, V. C. (1998). Socioeconomic disadvantage and child development. American_Psychologist, 53, 185-204.

Meertens, R. W., Blickenstaff, J., \& Moravcsik, M. (1982). Scientific output in the third world. Scientometrics, 4(2), 135-169.

Mueller, C. W., \& Parcel, T. L. (1981). Measures of socioeconomic status: Alternatives and recommendations. Child Development, 52, 13-20.

Nakao, K., \& Treas, J. (1990). On revising prestige scores for all occupations (NORC General Social Survey Methodological Report No. 69).

Neisser, U., Boodoo, G., Bouchard, T. J. J., Boykin, A. W., Brody, N., Ceci, S. J., Halpern, D. F., Loehlin, J. C., Perloff, R., Sternberg, R. J., \& Urbina, S. (1996). Intelligence: Knowns and unknowns. American Psychologist, 51, 77-101.

Nunes, T. (1993). Psychology in Latin America: The case of Brazil. Psychology and_Developing Societies, 5, 123-133.

Ostrove, J. M., \& Adler, N. E. (1998). Socioeconomic status and health: Clinical psychology and behavioural medicine. Current Opinion in
Psychiatry, 11(6), 649-653.

Ostrove, J. M., Adler, N. E., Kuppermann, M., \& Washington, A. E. (2000). Objective and subjective assessments of socioeconomic status and their relationship to self-rated health in an ethnically diverse sample of pregnant women [Electronic version]. Health Psychology, 19, 613-618.

Over, R. (1978). Journal ranking by citation analysis: Some inconsistencies. American_Psychologist, 33, 778-780.

Over, R. (1982). Collaborative research and publication in psychology. American Psychologist, 37, 996-1001.

Palacios, J. (1990). Parents ideas about the development and education of their children: Answers to some questions. International Journal of Behavioral Development, 13, 137-155.

Pascual, L., Galperín, C. Z., \& Bornstein, M. H. (1995). La medición del nivel socioeconómico y la psicología evolutiva: El caso Argentino [Measurement of socioeconomic status and developmental psychology: The Argentine case]. Revista Interamericana de Psicologia/Interamerican Journal of Psychology, 27, 59-74.

Ribas, R. de C., Jr. (2001). Indexes of socioeconomic status in psychological research: A brief review. Unpublished manuscript, Universidade Federal do Rio de Janeiro, Rio de Janeiro.

Robins, R. W., Gosling, S. D., \& Craik, K. H. (1999). An empirical analysis of trends in psychology. American Psychologist, 54, 117-128.

Rogler, L. (1996). Increasing socioeconomic inequalities and the mental health of the poor. The Journal of Nervous \& Mental Disease, 184, 719-722.

Rowe, D. C., \& Rodgers, J. L. (1997). Poverty and behavior: Are environmental measures nature and nurture? [Electronic version]. Developmental Review, $17,358-375$.

Sameroff, A. J., \& Feil, L. A. (1985). Parental concepts of development. In I. E. Sigel (Ed.), Parental belief systems: The psychological consequences for children (pp. 83-105). Hillsdale, New Jersey: Lawrence Erlbaum.

Simons, R. L., Lorenz, F. O., Wu, C.-I., \& Conger, R. D. (1993). Social network and marital support as mediators and moderators of the impact of stress and depression on parental behavior. Developmental Psychology, 29, 368-381.

Smith, T. E., \& Graham, P. B. (1995). Socioeconomic stratification in family research. Journal of Marriage \& the Family, 57, 930-941.

Sobal, J., \& Stunkard, A. J. (1989). Socioeconomic status and obesity: A review of the literature. Psychological Bulletin, 105, 260-275.

Spinak, E. (1998). Indicadores Cienciométricos. Ciência da Informação, 27(2), 141-148.

Suzuki, L. A., \& Valencia, R. R. (1997). Race-ethnicity and measured intelligence: Educational implications. American Psychologist, 52, 11031114.

Sylvain, C. (1993). Canadian research activity in aquaculture: A bibliometric analysis. Scientometrics, 27(3), 295-376.

Treiman, D. J. (1977). Occupational prestige in comparative perspective. New York: Academic.

United Nations Development Programme [UNDP]. (2001). Human Development Report 2001 [Electronic version]. New York: Oxford University Press.

Vidal, E. Q., Ferrandiz, Hernandez, A. S., \& Linares, M. J. P. (1991). La segunda década de la Revista Latinoamericana de Psicología (1979-1988): Una aproximación objetiva de la psicología en latinoamerica. Revista Latinoamericana de Psicología, 23(2), 155-181.

Warren, J. R., \& Hauser, R. M. (1997). Social stratification across three generations: New evidence from the Winsconsin Longitudinal Study. American Sociological Review, 62, 561-572.

White, H. D., \& McCain, K. W. (1989). Bibliometrics. Annual Review of Information Science and Technology, 24, 119-186.

WHO - International Consortium in Psychiatric Epidemiology [WHO-ICPE]. (2000). Cross-national comparisons of the prevalences and correlates of mental disorders. Bulletin of the_World Health Organization, 78, 413426. 
Rodolfo de Castro Ribas Jr. is a doctoral student and an Assistant Professor at Universidade Federal do Rio de Janeiro.

Maria Lucia Seidl de Moura, doctor in Cognitive Psychology, Fundação Getúlio Vargas, is a Full Professor at Universidade do Estado do Rio de Janeiro.

Isabela Dias Soares is a psychologist and a master degree student at Universidade Federal do Rio de Janeiro. Alessandra Aparecida do Nascimento Gomes is a psychologist and has a master degree in Social Psychology from Universidade do Estado do Rio de Janeiro.

Marc H. Bornstein is a Senior Investigator in the National Institute of Child Health and Human Development, Bethesda, Maryland, U.S.A.

Correspondence concerning this article should be addressed to Rodolfo de Castro Ribas Jr.; Rua Ferreira Pontes, 286 Apt. 1007A (Andaraí); Rio de Janeiro, RJ; CEP 20541-280 - Brazil. E-mail: rribas@ufrj.br 